\title{
Cancellation of Deed of Sale and Purchase Agreement Made Before Notary Public (Study at Notary Office of West Nusa Tenggara Province)
}

\author{
Muhammad Taufik Yanuar Ramadhan ${ }^{1} \quad$ Salim HS $^{2} \quad$ Djumardin $^{2}$ \\ 1.Graduate Program Student in Notary, Faculty of Law, Mataram University, Indonesia \\ 2.Lecturer of Faculty of Law, Mataram University, Indonesia
}

\begin{abstract}
This study aims to explain and analyze more clearly the factors that cause the cancellation of the sale and purchase agreement deed made before a Notary in West Nusa Tenggara Province and to explain and analyze the legal consequences of the cancellation of the sale and purchase agreement deed made before a notary public. This research method is empirical legal research with a statutory approach, conceptual approach and sociological approach. Based on the research results obtained are: First, the factors that cause the cancellation of the Sale and Purchase Agreement deed made in front of a notary are the parties agreeing to cancel the sale and purchase agreement because the agreed price issue is not paid by the buyer until the agreed time period, The land documents required for the transfer of land rights have not been completed until the agreed period of time. The object is in dispute. The parties do not pay taxes. Second, the legal consequence of the cancellation of a sale and purchase agreement made before a notary is that the parties must first fulfill their obligations as agreed, namely the fulfillment of the obligations contained in the Deed, fulfillment of the agreement accompanied by compensation, compensation, cancellation of the agreement, cancellation accompanied by compensation loss.
\end{abstract}

Keywords: Agreement, Cancellation, Deed, Notary.

DOI: $10.7176 / \mathrm{JLPG} / 112-05$

Publication date:August $31^{\text {st }} 2021$

\section{INTRODUCTION}

Notary in making a deed does not take sides and safeguards the interests of the parties objectively. With the help of Notary Public the parties who make the Sale and Purchase Agreement will get assistance in formulating the matters to be promised. But an agreement can not always run in accordance with the agreement desired by the parties under certain conditions can be found the occurrence of various things, resulting in an agreement being cancelled, either cancelled by the parties or by order of a court ${ }^{1}$.

Considering the Trade And Purchase Agreement is a legal act that precedes the process of transfer of land rights. As a form of, this Sale and Purchase Agreement contains the rights and obligations of the parties who made it, so that if the matters agreed in the Sale and Purchase deed are violated or not fulfilled by the parties who made it then then it can be said that there has been a default, due to the default, the Land Sale agreement in practice is possible to be canceled either unilaterally by either party or by the agreement of both parties and can also be annulled by the decision of the Court.

By cancelling the Land Sale and Purchase Agreement made before the Notary Public will have an impact for the seller and buyer, namely certain juridical consequences for the parties who make it. Based on the description above, the author is interested in conducting research in the Province of West Nusa Tenggara especially in the West Lombok Regency and North Lombok Regency.

Based on the background above, research will be conducted on the cancellation of the deed of trade agreement made before the Notary Public.

The problem in this study is about what factors caused the cancellation of the deed of trade agreement made before the Notary in the Province of West Nusa Tenggara and the legal consequences of the cancellation of the deed of trade agreement made before the Notary Public. Thus the purpose of this study is to explain and analyze what factors caused the cancellation of the deed of trade agreement made before the Notary public in the Province of West Nusa Tenggara and the legal consequences of the cancellation of the deed of trade agreement made before the Notary.

\section{RESEARCH METHODS}

This type of legal research uses empirical legal research. The approaches used in this study are The Statutory Approach, Conceptual Approach and Sociological Approach. Types and data sources used in this study is secondary data, data sources obtained through literature studies and document studies. ${ }^{2}$ Primary data, is data derived from field data obtained from respondents and informants. The location of the research to obtain data

\footnotetext{
${ }^{1}$ Setiawan Rahmat, Pokok-Pokok Hukum Perikatan, Putra Abardin, Bandung, 2005, hlm. 6.

${ }^{2}$ Muhaimin, Metode Penelitian Hukum, Mataram University Press, Mataram, 2020, hlm. 124.
} 
related to the completion of this thesis was conducted in the Province of West Nusa Tenggara, especially in the West Lombok Regency and North Lombok Regency. Data collection techniques are carried out by secondary data collection methods, namely by collecting, documenting books, journals, scientific papers, dictionaries, encyclopedias and documents ${ }^{1}$ and Primary data collection techniques where in empirical legal research there are three data collection techniques that can be used, either used individually or separately or used together at once. The three data collection techniques are interviews, questionnaires or questionnaires and observations. ${ }^{2}$ Data analysis is conducted with qualitative data analysis and the conclusion to this study is to use deductive methods.

\section{RESULT AND DISCUSSION}

A. Factors That Can Cause The Cancellation of the Deed of Sale and Purchase Agreement Made before a Notary Public.

The factors behind the cancellation of the Land Sale and Purchase Alliance The ever-dynamic development of the community will bring about a variety of needs. Land is a very high value asset, especially in the community, West Nusa Tenggara It has a higher impact on the need for the community for the availability of land. Land transactions are a legal act that is often done by the community to meet these needs. The transfer of land rights by means of land purchase must be done in front of authorized public officials. In the provisions of Article 37 of Government Regulation No. 24 of 1997 concerning Land Registration mentioned that the transfer of rights to land and property rights to units of flats through buying and selling, exchanging, grants, income in the company and other legal acts of transfer of rights, except the transfer of rights through auction, can only be registered, if proven by a deed made by the authorized PPAT in accordance with the provisions of the applicable laws and regulations. But in practice, there is also before the creation of a deed of sale and purchase of land made by and before the PPAT authorized in advance by the parties made an agreement known as a sale and purchase agreement. Land Sale and Purchase agreement made in the form of notarial deed appears as a legal need of the community in daily life has been widely practiced in the notary office.

Because the sale and purchase agreement is a preliminary agreement, it usually contains promises from the parties which contain provisions when the conditions for the actual sale and purchase are fulfilled. Of course, the parties after the conditions for the sale and purchase have been met can meet again (for the obligation to sell and buy in front of a general official who has the authority to carry out the sale and purchase).

In a land sale and purchase agreement, it can be said as an agreement in which both parties bind themselves to conduct a sale and purchase, if things that cannot be fulfilled at the time of the sale and purchase agreement are carried out, usually related to the unpaid price or land certificates. that doesn't exist yet.

According to the author, this is different from buying and selling as referred to in the Civil Code as stipulated in Book III Chapter 5 (Articles 1457-1540). Buying and selling which in Dutch is called "koop en verkoop" is an agreement / agreement (overeenkomst) whereby the party who is one seller binds himself to hand over an object (zaak), while the other party buyer to pay the promised price (Article 1457). General provisions (properties) and rights and obligations of the parties: the seller and the buyer, as soon as they agree on the object and price in question even though both the object and its price have not been submitted and paid.

The transfer of property rights to the goods sold only occurs if levering has been made. The handover in the sale and purchase is a transfer of goods that have been sold into the power (macht) and the property (bezit) buyer. If the item sold is a particular item, if the parties do not specify other, then this item from the moment of purchase is the responsibility of the buyer, although the delivery has not been made, and the seller may (entitle to) demand the price. Thus the sound of Article 1460, which according to legal experts is a dead article.

About the (main) obligation of the seller to the buyer, i.e. :

- deliver the goods/objects in question;

- bear/guarantee (vrijwaren);

- possession of the sold objects safely and peacefully (rustig en vreedzaam);

- hidden defects (verborgen gebreken) of the object in question or in such a way as to publish the reason for the cancellation of the sale.

The Buyer has the primary obligation to pay the price of what he purchased, at the time and in place as stipulated in accordance with the agreement/agreement in respect of the additional rules that if the parties do not specify it, the payment shall be made on the spot at the time of delivery of the object.

If the buyer does not pay the price of the item he bought, the seller can demand the cancellation of the sale and purchase concerned. Regarding the sale and purchase of merchandise and household goods (waren en meubelen) there is an exception, namely that in the interests of the seller, the sale and purchase is automatically canceled if the goods are not taken at the time determined by the parties.

According to the author, a land sale and purchase agreement can be classified into a conditional agreement.

\footnotetext{
${ }^{1}$ Ibid., hlm. 101 .
}

2 Ibid, hlm. 95. 
This can be seen based on the provisions of Article 1253 of the Civil Code which states: An engagement is conditional if it is hung on an event that is still to come and it is still not certain that it will occur, either by suspending the engagement until such an event occurs according to the event or not.

A conditional engagement is opposed to a pure engagement, which is an agreement that does not contain a condition. A condition must be explicitly stated in the engagement. The law determines the conditions that may not be included in an engagement, namely :

1. aims to do something that is impossible to do;

2. contrary to decency;

3. prohibited by law;

4. its implementation depends on the willingness of the person bound. One of the important conditions in a reciprocal agreement is broken promises. "Breaking the promise is a condition for invalidation" (Article 1266 of the Civil Code). The condition for canceling is considered always in a reciprocal agreement. If the cancellation condition occurs, the agreement is not null and void from a legal perspective, but the cancellation must be requested from the judge. The request must also be made even though breaking the promise as a condition for canceling is stated in the agreement.

5. sale and purchase agreements are also related to an agreement with a timeframe. Because an engagement with a timeline is an engagement that does not suspend the engagement, but only suspends its implementation. Provision of time that can suspend or terminate the engagement.

The sale and purchase agreement contains the rights and obligations of the parties who make it, so that if the things that have been agreed in the agreement deed are violated or not fulfilled by the parties who made it, it can be said to be in default, which results in a sale and purchase agreement. may be canceled unilaterally by one of the parties or on the agreement of both parties.

There may also be circumstances where the sale and purchase has been paid in full, but because the taxes in the sale and purchase are too large, or the object to be sold is still in installments of the seller (as the debtor) of a bank (as a creditor) but before making a transaction needs to be requested prior permission from the creditors,or the object being traded turns out to be still a collateral or debt guarantee from the seller and will only pay off the debt when it has received repayment from the buyer, but this also requires prior permission from the bank (creditor or guarantee recipient). In order to overcome this, then a land sale and purchase agreement is made as a preliminary agreement while waiting for the fulfillment of the conditions for the main agreement, namely sale and purchase before the PPAT which is authorized to make it.

The Officials for Making Land Deeds (PPAT) are only authorized to make deeds of transferring land rights. PPAT is not authorized to make a sale and purchase agreement deed. the sale and purchase agreement is not a law of transfer of land rights. If an authentic deed is needed, the one who is authorized to make it is a notary. Each deed made by a Notary must be witnessed by two witnesses. The presence of two witnesses is an absolute condition that cannot be avoided so that the deed has an authentic character, because it can be said that the witnesses are an inseparable instrument from a notary deed. With the help of a notary, the parties who make a land sale and purchase agreement will receive assistance in formulating matters to be agreed upon.

The land sale and purchase agreement is a preliminary agreement, so usually in the agreement makes promises from the parties which contain provisions when the conditions for the sale and purchase before the Land Deed Making Official (PPAT) have been fulfilled. After the conditions for the sale and purchase have been met, the parties can come back to carry out the sale and purchase in front of the Land Deed Maker (PPAT). However, there is a possibility that the prospective seller will be unable to come back to sign the sale and purchase deed.In order to overcome this, the buyer is given the power to be able to sell and buy himself, either representing the prospective seller or himself as a potential buyer before the authorized Land Deed Making Official (PPAT). In addition to the power of attorney, usually the prospective seller also gives the prospective buyer the authority to be able to generally represent the management rights of the said land as long as the sale and purchase has not been carried out before the authorized Land Deed Maker (PPAT).

Based on the research results, it can be seen the reasons for the agreement deed for the sale and purchase of land by and in front of a notary public ${ }^{1}$ :

1. Payment for land objects being traded has not been made in full by the buyer. In this case the payment is made in stages based on the agreement between the seller and the buyer;

2. The land object being traded does not have a certificate which is a valid proof of ownership of the land.

3. The land to be sold has been registered and the land certificate process is still ongoing at the land office;

4. The seller or buyer does not yet have the money to pay Income Tax or Acquisition Fee on Land Rights, if the sale and purchase is made in a PPAT deed;

5. And or there are still deficiencies in the documents needed to make a sale and purchase deed before

\footnotetext{
${ }^{1}$ Berdasarkan wawancara dengan Notaris DR. Nining Herlina, S.H.,M.Kn, Notaris di Kabupaten Lombok Barat, tanggal 5 April 2021, pukul 13.00 WITA.
} 
PPAT, which document is in the process of being processed.

The requirements that must be met by the parties in order to make a land purchase agreement deed are ${ }^{1}$ :

1. The Seller and the Buyer are present before the Notary and sign the land sale and purchase agreement;

2. The Parties submit:

a. Land certificate if it already has a certificate

b.Certificate of Land for those who have not been certified

c. Photocopy of Seller and Buyer ID card (KTP)

d.Notification of tax due Land (SPPT)

e. Certificate of Land Not in Dispute

f. Proof of property tax Payment (PBB)

g.Certificate of Inheritance and Death issued by the sub-district if there is an heir

h.Power of attorney and ID card (KTP) of the recipient of the power of attorney if authorized

The contents of the sale and purchase agreement can be described as follows:

1.Agreement The parties agree and wish to enter into a sale and purchase agreement, where the first party binds itself to sell to the second party, namely regarding the object of a plot of land

2.The parties explained that they do not need explanation and further details of what is traded because what is traded in the deed they already know together with the parties further confirm that this trade agreement takes place according to or the provisions of the following terms:

a. The parties' agreement regarding the price

b. Payments are made in stages

c. The remaining payment is made after the certificate issuance process is complete

d. If the second party does not pay the remaining payment after the issuance of the certificate, the parties still agree to settle it by deliberation and consensus if in the future the object is problematic or in dispute then the first party is obliged to refund all costs that have been received by the second party

e. The first party and the second party have mutually agreed that this trade will not end because of the death / fall of bankruptcy or dissolution of one of the parties, but also applies to the heirs of each party according to the provisions of the law applicable to the heirs of each party according to the provisions of applicable law

f. Because the first party has received the money, the first stage payment is from the second party, then the price fixing for the plot of land above cannot be changed by both parties.

g. The first party bears to the second party that he is the only party entitled / authorized to sell what is traded according to this deed, therefore the first party will continue to settle at its own risk and burden on all legal issues that arise or may be in the future, about the ownership of what is being traded.

h. Both parties have mutually agreed and agreed that the seller's tax costs shall be borne by the first party, buyer tax costs, certificate transfer fees and notary fees borne by the second party.

i. Even though the second party has provided the down payment as stated in this deed, physical control of the land cannot be exercised by the second party, except when the land price has been paid in full by the second party to the first party and at the same time signing an official sale and purchase deed before the official authorized.

j. The first party promises and bears to the second party that everything that is traded in this deed is the right and property of the first party itself, is not guaranteed as debt, and is not involved in a case or demand or lawsuit from anyone.

k. Other matters that have not been or are not sufficiently regulated in this deed, as far as possible will be decided together by the two parties by way of deliberation and consensus.

1. Other matters that have not been or are not sufficiently stipulated in this act, as far as possible will be decided jointly by both parties by way of deliberation and consensus

$\mathrm{m}$. Other matters that have not been or are not sufficiently stipulated in this act, as far as possible will be decided jointly by both parties by way of deliberation and consensus

n. Furthermore, the sale and purchase to be carried out is carried out with the usual terms and agreements for a sale and purchase of land, the terms and agreements have been known by the parties.

However, in the course of an agreement, it does not always run according to the agreement of the parties that made it, there are certain conditions that result in an agreement having to end not in accordance with the original agreement. From the research results, there are several factors that led to the cancellation of the sale and

\footnotetext{
${ }^{1}$ Berdasarkan wawancara dengan Notaris DR. Nining Herlina, S.H.,M.Kn, Notaris di Kabupaten Lombok Barat, tanggal 5 April 2021,
} pukul 13.00 WITA. 
purchase deed, namely:

Whereas because there are things and other things that have not been fulfilled by the parties in the agreement deed that they have agreed on, the parties confirm, agree and agree to enter into an agreement between them, namely signing the deed of cancellation of the sale and purchase agreement, which contains ${ }^{1}$ :

1. Agreement to sign a deed of cancellation of a sale and purchase agreement

2. The parties have mutually agreed to make calculations of the obligations they have agreed to complete based on the cancellation deed

3. The parties explain that with this cancellation deed they have mutually provided settlement and release and they mutually support each other, which is why they promise not to mutually make claims, indictments and / or demands of any kind.

Cancellation of a sale and purchase agreement can occur because it has been regulated in the agreement itself and is desired by the parties making the agreement. The reasons for cancellation of the agreement generally specify the reasons, so that one or both parties can cancel the agreement. As in practice, the factors that cause the cancellation of the sale and purchase agreement deed made before a notary are because the parties do not fulfill the contents of the agreement made, for example, the things stated in the agreement include, namely:

a. The sale and purchase price that has been agreed in the land sale and purchase agreement is not paid by the buyer until the agreed period of time.

b. The land documents required for the process of transferring land rights (land sale and purchase before the Land Deed Authorization Officer) have not been completed until the agreed period of time.

c. The object of sale and purchase is in a dispute.

d. The parties do not pay off their tax obligations.

e. the land sale and purchase agreement was cancelled by the parties Cancellation of the trade agreement aimed at bringing both parties back to the circumstances before the agreement was held. If one party has fulfilled its performances, it can sue the other party who made a default to return or if it is no longer possible, the performances that have been done are assessed with money. Thus, performances that have already been received must be returned.

Not all defaults can cause one party to cancel the agreement, but only defaults are mentioned in the agreement, another way of cancellation of the agreement mentioned in the agreement is by agreement of both parties, in fact this is just an affirmation, because without mention of it, for the sake of law, the agreement can be terminated if agreed by both parties.

Cancellation of the agreement aims to bring both parties back to the state before the agreement was held. If one party has received something from the other party, either money or goods, then the money or goods must be returned. Unilateral cancellation of a sale and purchase agreement can be interpreted as the unwillingness of one of the parties to fulfill the performances agreed by both parties in the sale and purchase agreement. At a time when the other party still intends to fulfill the performances that it has promised and wants to continue to receive counter-performances from the other party ${ }^{2}$.

B. Legal Consequences Than Cancellation of Sale and Purchase Agreement Deed Made Before Notary Public In practice, the Deed of Sale and Purchase Agreement is made in the form of an authentic deed made before a Notary Public, so that the Deed of Sale and Purchase Agreement is an authentic deed that has perfect evidentiary power. This is intended by the parties to provide more protection and legal certainty for the parties who make it, because the Notary in making the deed is impartial and protects the interests of the parties objectively, with the help of the Notary the parties who make the sale and purchase agreement will get assistance in formulating matters. -things to be promised. However, an agreement is not always able to run according to the agreement desired by the parties, under certain conditions various things can be found, resulting in a cancellation of an agreement, whether canceled by the parties or by court order.

In principle an agreement that has been made may be canceled if the agreement in its implementation will harm certain parties. These parties are not only parties to the agreement, but also any individual who is a third party outside of the parties to the agreement. In this case the cancellation of the agreement may occur, either before the agreement is implemented or after the agreed performances are carried out under the agreement made.

It is possible for a land sale and purchase agreement to be canceled unilaterally by one of the parties or upon the agreement of both parties. Even the land sale and purchase agreement can also be canceled by a court decision. The cancellation of an authentic agreement deed will certainly have certain juridical consequences.

An agreement made by a notary deed can be null and void by law or canceled based on a decision of a judge who has permanent legal force (in kracht). To find out that an agreement made legally can be canceled within the period of the agreement is valid and what are the consequences of the cancellation of the agreement

\footnotetext{
${ }^{1}$ Berdasarkan wawancara dengan Notaris DR. Nining Herlina, S.H.,M.Kn, Notaris di Kabupaten Lombok Barat, tanggal 5 April 2021, pukul 13.00 WITA.

${ }^{2}$ Berdasarkan wawancara dengan Notaris DR. Nining Herlina, S.H.,M.Kn, Notaris di Kabupaten Lombok Barat, tanggal 5 April 2021 , pukul 13.00 WITA.
} 
can be seen from the clause which regulates the possibility of cancellation of the agreement along with the causes and consequences for the parties in the agreement ${ }^{1}$.

Based on Article 1266 of the Civil Code (KUHPerdata), the agreement cannot be canceled automatically when the debtor has actually neglected his obligations, but the cancellation of the agreement must be requested to the judge. If the Judge with his decision has canceled the agreement, the legal relationship between the parties that originally entered into the agreement is also canceled so that each party no longer needs to fulfill his performances. The ratio of the provisions of this article is appropriateness because it is considered to be contrary to justice and morality if one party gets a performances without doing his own performances.

Cancellation claims can only be made against a reciprocal agreement. A reciprocal agreement is an agreement in which each party binds itself to perform their performances and vice versa, the opposite party is entitled to performance. In a unilateral agreement can not be prosecuted for cancellation based on Article 1266 of the Civil Code (KUH Perdata) because in a one-sided agreement the obligation to perform performance is only on one of the parties and demands for cancellation are actually a way to free themselves from the obligation to perform the performances for parties who do not do the default.

The provisions of Article 1266 of the Civil Code are regulating, so that the parties can set aside the article as in the land sale and purchase agreement made between the land owner and the one which includes a clause overriding the enactment of Article 1266 of the Civil Code. Therefore it must be stated in its agreement that the rights held by the parties under the provisions of the article have been expressly waived. In notary practice it often happens that in a reciprocal agreement such as a trade agreement with or without conditions canceled therein, it is stated that the parties waive Articles 1266 and 1267 of the Civil Code.

Sidelining the provisions of Article 1266 of the Civil Code in the agreement on the sale and purchase of the land, the cancellation of the agreement should not be requested through the Judge in the event of a default made by either party. Thus, landowners can demand the cancellation of the agreement without going through the Judge against defaults made due to negligence in making payments.In practice the view is accepted that if the parties agree to set aside Article 1266 of the Civil Code, in the event of default, the agreement will be null and void without the mediation of the judge's decision.

Article 1267 of the Civil Code, states that the party against whom it is not fulfilled can have rights, if this can still be done, it will force the other party to fulfill the agreement or it will demand the cancellation of the agreement accompanied by compensation for costs, losses and interest. Based on this article, the land owner is given the right to choose whether to demand the fulfillment or cancellation of the agreement with compensation for expenses, losses and interest. This article is an exception to Article 1338 of the second part of the Civil Code which states that an agreement cannot be withdrawn other than by the agreement of the two parties.

The land owner only demands compensation, then the land owner is deemed to have given up his right to request fulfillment and cancellation of the agreement. Meanwhile, if the land owner only demands fulfillment, the claim is not actually a sanction for negligence because fulfillment is already the ability to carry it out, however, there is a possibility for those who neglect to rid themselves of that negligence by fulfilling obligations, even though they have been declared negligent.

The right of the land owner to be able to sue the negligent arises from the existence of a legal relationship between two parties which means that the land owner's rights are guaranteed by law or statute. So that if these demands are not fulfilled voluntarily, the land owner can sue them in front of the judge. In conclusion, if the land owner is in default, the land owner can choose between several possible claims as referred to in Article 1267 of the Civil Code.

To the party against whom one is not fulfilled is given a choice, such as:

1. The usual legal tool, namely the court's claim to comply with indemnification or damages only without the claim of fulfilling the agreement.

2. Special legal tool, namely the claim to cancel reciprocity followed by a claim for compensation, on the basis that in any reciprocity is considered void if one party does not meet its obligations.

Although the parties do not include a condition for cancellation in a reciprocal, the law considers that the condition for cancellation exists.

In this connection, a legal protection is needed for the fulfillment of the rights of the land owner. Legal protection for the fulfillment of the rights of the parties if one of the parties defaults in the land sale and purchase agreement is highly dependent on the provisions of the land sale and purchase agreement made. If the sale and purchase agreement is not made before a notary public, then the protection of the deed is as an underhand deed only, whereas if it is made before a notary, the deed automatically becomes a notary deed so that the power of protection is in accordance with the protection of the authentic deed.

In practice, land sale and purchase agreements are often made in the form of an authentic deed drawn up

${ }^{1}$ Berdasarkan wawancara dengan Notaris Jurianto Ardiansyah, S.H.,M.Kn, Notaris di Kabupaten Lombok Utara, tanggal 12 April 2021, pukul 09.00 WITA. 
before a notary public, so that the sale and purchase agreement deed is an authentic deed that has perfect evidentiary power. This is intended by the parties to provide more protection and legal certainty for each party, so the form of a written land sale and purchase agreement will certainly make it easier for the parties to resolve disputes if it occurs later ${ }^{1}$.

Cancellation claims can only be made against a reciprocal agreement. A reciprocal agreement is an agreement in which each party binds itself to perform performances and vice versa, the opposite party is entitled to performances. In a one-sided agreement can not be prosecuted for cancellation based on Article 1266 of the Civil Code because in a one-sided agreement the obligation to perform is only on one party and demands for cancellation are actually a way to free oneself from the obligation to perform their performances for parties who do not do a default.

If the parties reach the prosecution in the Court then it can be canceled the deed of agreement or otherwise continued the deed of agreement until the settlement of installments. If cancelled there are consequences of claims for damages, interest, and fines demanded to the Court from the party who feels aggrieved at the cancellation of the agreement to the party that canceled.

The legal consequence of the cancellation of the sale and purchase agreement made before a Notary is that there will be a claim for compensation from the party who feels that he has been aggrieved for the cancellation of the land sale and purchase agreement. The compensation lawsuit can be filed to the court (litigation), after being preceded by a warning (somatie) which is sent by the party who feels aggrieved to the party who canceled or the party who has defaulted / failed to promise in the sale and purchase agreement.

In practice, land sale and purchase agreements are often made in the form of an authentic deed made before a notary public, so that the land sale and purchase agreement is an authentic deed that has perfect evidentiary power. This is intended by the parties to provide more protection and legal certainty for each party, so the form of a written land sale and purchase agreement will certainly make it easier for the parties to resolve disputes if it occurs at a later date.

The parties who make a sale and purchase agreement will receive assistance in formulating the matters to be agreed upon. However, an agreement cannot always run according to the agreement desired by the parties. In certain conditions it can be found that various things have occurred, which resulted in an agreement being canceled, either canceled by the parties or by court order. From this point of view, the implementation of the land sale and purchase agreement is interesting for further study considering that the sale and purchase agreement is a legal act that precedes the process of transferring land rights. As a form, the land sale and purchase agreement contains the rights and obligations of the parties making it, so that if the things that have been agreed in the sale and purchase agreement are violated or are not fulfilled by the parties making it, it can be said that there has been a default.

A land sale and purchase agreement made before a Notary Public does not result in the transfer of the land title at that time from the hands of the land owner to the prospective buyer. This is because the sale and purchase agreement is a conditional agreement or preliminary agreement prior to the implementation of the sale and purchase agreement through the official deed of the Deed of Land Deed (PPAT). As it is known that the agreement is the source of. As it was made deliberately at the will of the parties, then everything that has been agreed upon by the parties must be carried out by them. As a form of agreement, the land sale and purchase agreement contains the rights and obligations of the parties who make it. These rights and obligations which are stated in an agreement are referred to as performances. performance is something that must be fulfilled by debtors and creditors in each. performance is the content of the engagement.

According to the provisions of Article 1234 of the Civil Code, there are three possible forms of performance, namely giving something, doing something, or not doing something. The performance of giving something is aimed at giving up an object to be enjoyed or owned or returning an object to be controlled or enjoyed by the creditor, for example a lease agreement or a sale and purchase agreement.

If the things that have been agreed upon in the said sale agreement are violated or are not fulfilled by the parties making them, it can be said that there has been default. That is, the form of negligence made in the form of being late in making payments in fulfilling obligations can be said to be default. Thus, default is the failure to carry out an agreement due to error or negligence or broken promises from the parties to the agreement. One of the parties is considered as the default or poor performances, if:

a. Do not do what he was determined to do.

b. Carry out what was promised but not as it should.

c. Do what was promised but too late.

d. Doing something that according to the agreement should not be done

The party accused of default can submit several reasons to defend himself, namely:

${ }^{1}$ Berdasarkan wawancara dengan Notaris Jurianto Ardiansyah, S.H.,M.Kn, Notaris di Kabupaten Lombok Utara, tanggal 12 April 2021, pukul 09.00 WITA. 
a. There is a state of force (overmacht)

b. The buyer himself has been negligent

c. The buyer has given up his right to claim compensation

If he has been warned or has firmly billed his promise and still does not perform his performance, then he is in a state of neglect or neglect, sanctions can be given, namely compensation and cancellation of the agreement. However, because default has such important consequences, it must be determined in advance whether to commit default and if this is denied, must prove it before the Judge.

Article 1238 of the Civil Code regulates how to warn a debtor so that he can be said to be in default if he does not fulfill the warning. Article 1238 of the Civil Code states that: the debtor is negligent, if by means of a warrant or a similar deed it has been declared negligent, or for its own sake if it stipulates that the person in debt will have to be considered negligent by the expiration of the stipulated time.

Thus, in defaulting, the law obliges the land owner to provide a statement of negligence. The statement of negligence is an affirmation, which has not performed at the time specified in the statement of negligence, then at that time it is sufficient evidence that is negligent and responsible for all the consequences. The warning (sommatie) must be made in writing with a warrant or similar deed made and delivered by a bailiff, and the judge will not consider an oral warning valid. However, the obligation to provide a statement of negligence can be eliminated by making provisions in the agreement regarding when or in which cases it can be considered to have committed default, such as stating that default is sufficiently proven by the time of payment or since the time of actions which are prohibited according to agreement made by the parties, without the need for a written statement from the land owner.

The exception is because the articles regarding the contract law regulated in the Civil Code (KUHPerdata) are only regulatory (not coercive) and the principle of freedom of contract stipulated in Article 1338 of the Civil Code applies so that the parties are allowed to make self-regulation as long as it does not contradict the law, public order and decency. In the practice of a notary public, he also often clearly determines in every reciprocal agreement made before him that just by passing the allotted time for doing a performances is sufficient evidence for both parties that one of the parties has been negligent.

This land sale and purchase agreement serves as a means of proof if one of the parties is in default and to make it based on the agreed articles. Forms of default that can occur in a land sale and purchase agreement, such as :

1. The buyer delays payment of the land price which should have been paid or has only paid a few days after maturity, or the buyer makes payments but not as promised.

2. The buyer does not pay a penalty for the late price of the land or the late payment of the fine.

3. The seller takes actions that clearly violate the land sale and purchase agreement, for example selling the object of the agreement to another party.

The land sale and purchase agreement did not end because one of the parties passed away. a land sale and purchase agreement can be decided by both parties. The seller can terminate the land sale and purchase agreement if the buyer is unable to continue his obligation to pay the land price as agreed. In addition, if the buyer resigns or cancels the transaction for any reason, the land sale and purchase agreement can be terminated.

The buyer can also decide on a land sale and purchase agreement in a situation where the seller cannot deliver the object and the rights attached to it in accordance with the agreed period of time, and does not match the floor plan or technical specifications of the building as agreed. If this situation occurs, the seller is obliged to return what has been received, added with fines, interest and other costs in accordance with applicable regulations.

One of the parties to the agreement does not carry out the agreed performances, then the other party to the agreement has the right to enforce its implementation through the mechanisms and legal channels in force. The enforcement and implementation of the agreement can only be carried out by one or the parties to the agreement against the other party in the agreement as confirmed in the personnel principle of an agreement.

a land sale and purchase agreement made with a Notary deed contains the rights and obligations of the parties making it. In a land sale and purchase agreement, the buyer has the obligation to pay the price of the land at the time and place as stipulated according to the agreement in the sale and purchase agreement between the buyer is required to pay the land price in installments of several times.

An engagement is fulfilled if the contents of the engagement are paid in full. With the complete fulfillment of the contents of the agreement, the agreement has achieved its goal so that the legal relationship between the land owner is terminated and the agreement is canceled, but without paying the purchase price, the land owner can demand the cancellation of the purchase according to the provisions of Article 1517 of the Civil Code.

\section{CONCLUSION}

1. The factors that cause the cancellation of the Sale and Purchase Agreement deed made before a notary are:

a. the parties agreed to cancel the sale and purchase agreement because: 
1. the agreed price issue is not paid by the buyer until the agreed time period

2. the land documents required for the transfer of land rights have not been completed until the agreed period of time

3. Objects in dispute

4. The parties do not pay off in paying taxes;

a. Because the conditions for cancellation as stated in the sale and purchase agreement clause have been fulfilled, as stated in the sale and purchase agreement clause are fulfilled, and

b. cancellation by the court on the request of one of the parties who is usually one of the parties in default and elements of an unlawful act

2. There are several alternative legal consequences, namely as follows:

a. Fulfillment of the obligations set forth in the Deed.

b. Fulfillment of the agreement accompanied by compensation

c. Compensation.

d. Cancellation of agreement.

e. Cancellation accompanied by indemnification.

\section{REFERENCES}

\section{Book}

Muhaimin, Metode Penelitian Hukum, Mataram University Press, Mataram, 2020.

Setiawan Rahmat, Pokok-Pokok Hukum Perikatan, Putra Abardin, Bandung, 2005.

\section{Legal Regulations}

Kitab Undang-Undang Hukum Perdata, (Stbl. 1847-23).

Undang-Undang Nomor 2 Tahun 2014 tentang Perubahan Atas Undang-Undang Nomor 30 Tahun 2004 tentang Jabatan Notaris, (LN No. 117 Tahun 2004, TLN No. 4432).

\section{Internet}

https://www.hukumonline.com/klinik/detail/ulasan/lt550c0a7450a04/akta-notaris-sebagai-akta-otentik/ diakses pada tanggal 5 Januari, pukul 10.00 WITA.

https://www.hukumonline.com/klinik/detail/ulasan/cl4598/lingkup-kerja-notaris/ diakses pada tanggal 5 Januari, pukul 10.00 WITA.

https://www.inanews.co.id/2020/05/tugas-dan-wewenang-notaris-ppat/, diakses pada tanggal 4 Februari 2021 pukul 21.30 WITA.

\section{Interviews}

Berdasarkan wawancara dengan Notaris DR. Nining Herlina, S.H.,M.Kn, Notaris di Kabupaten Lombok Barat, tanggal 5 April 2021, pukul 13.00 WITA.

Berdasarkan wawancara dengan Notaris Jurianto Ardiansyah, S.H.,M.Kn, Notaris di Kabupaten Lombok Utara, tanggal 12 April 2021, pukul 09.00 WITA 